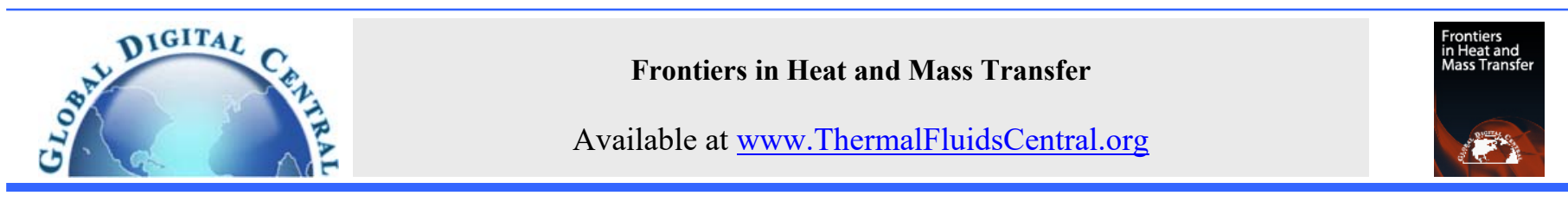

\title{
NUMERICAL INVESTIGATIONS ON FLOW STRUCTURE AND HEAT TRANSFER IN A SQUARE DUCT EQUIPPED WITH DOUBLE V- ORIFICE
}

\author{
Amnart Boonloi ${ }^{\mathrm{a}}$ and Withada Jedsadaratanachai ${ }^{\mathrm{b}, *}$ \\ ${ }^{a}$ Department of Mechanical Engineering Technology, College of Industrial Technology, King Mongkut’s University of Technology North Bangkok, \\ Bangkok 10800, Thailand \\ ${ }^{b}$ Department of Mechanical Engineering, Faculty of Engineering, King Mongkut's Institute of Technology Ladkrabang, Bangkok 10520, Thailand
}

\begin{abstract}
Numerical predictions on heat transfer characteristic, flow topology and thermal performance assessment in a square duct are presented. The passive technique, insertion of the vortex generator, is opted to develop the heat transfer rate in the square duct heat exchanger. The vortex generator of the present research is Double V-Orifice (DVO). The square duct equipped with DVO is tested with various parameters. The influences of DVO height, $\mathrm{b}$, to the duct height, $\mathrm{H}$, or $\mathrm{b} / \mathrm{H}$, gap spacing between the outer edge of the orifice and the duct wall, $\mathrm{s}$, to the duct height or $\mathrm{s} / \mathrm{H}$ and flow directions (tip-pointing-Downstream and tip-pointing-Upstream) on flow pattern and heat transfer profile are considered for laminar flow regime with similar pitch, $\mathrm{P}$, to duct height or $\mathrm{P} / \mathrm{H}$ of 1 . The Reynolds number, Re, based on the hydraulic diameter, $\mathrm{D}_{\mathrm{h}}$, of the square duct around $100-2000$ is discussed. The numerical model is solved with the commercial software (finite volume method). As the numerical result, the square duct inserted with the DVO offers greater Nusselt number, Nu, than the plain duct around 1.00-14.80 times. The maximum thermal enhancement factor, TEF, for the square duct inserted with the DVO is found to be about 3.60 depended on $\mathrm{s} / \mathrm{H}, \mathrm{b} / \mathrm{H}$ and flow direction. The flow and heat transfer profiles in the square duct inserted with the DVO are also illustrated.
\end{abstract}

Keywords: Double V-Orifice; heat transfer; square duct; flow profile; numerical prediction.

\section{INTRODUCTION}

The ability of heat transfer for heat exchanger devices or heat transfer system for many industries had been improved by many researchers. The researchers bring the passive technique to expand the efficiency and heat transfer rate of the heat exchanger systems. The passive method can remain the operation cost of the thermal process. The passive method has high potentiality to enhance heat transfer rate in the heat exchanger devices. The passive method is the insertion of the vortex generator in the thermal system to produce vortex flow or swirling flow. Various kinds of vortex generator or turbulator had been opted to develop the thermal process. The selection of the vortex generator depends on the application of the heat exchanger device and heat transfer process.

As the literature reviews, the advantages of the conical ring (Nakhchi and Esfahani (2019a), Nakhchi and Esfahani (2019b), Ibrahim et al. (2019), Mohammed (2019), Bahiraei et al. (2020c, d)) and baffle (Bahiraei et al. (2019), Bai et al. (2019), Wang et al. (2019), Liu et al. (2019), Bahiraei et al. (2019), Li et al. (2019), Bai et al. (2019), Chai et al. (2018), Chai et al. (2019), Ahmed et al. (2019), Boonloi and Jedsadaratanachai (2019c)) or rib (Ameur and Menni (2019), Karami et al. (2019), Cao et al. (2019), Chen et al. (2019), Arani and Moradi (2019), Bahiraei et al. (2020a)) are focused. The prominent point of the conical ring is the convenience for the installation and maintenance, while the rib and baffle give high heat transfer rate, especially, V-shape and wavy configuration. The combination of the vortex generator between the conical ring and the baffle likes "orifice" (Boonloi and Jedsadaratanachai $(2019 \mathrm{a}, \mathrm{b})$ ) is opted to grow the heat transfer ability of the heat transfer process for the square duct heat exchanger. The

*Corresponding author. Email: kjwithad@kmitl.ac.th
Double V-shape is selected for the orifice due to the Double V-shaped configuration of the rib and baffle has high performance to improve heat transfer rate. The new kind of the vortex generator is called "Double V-orifice" or DVO. The DVO may enhance heat transfer rate and thermal performance nearly as the V-rib or V-baffle, while the structure of the DVO has more stable than the other types of the vortex generators. The installation method of the DVO in the duct is also convenient as the installation of the conical ring and twisted tape (Bahiraei et al. (2020a)).

The investigation methods for the heat exchanger improvement include numerical and experimental studies. The credibility of the experimental result is higher than the numerical result. However, the spending of the experimental test is also higher than the numerical study. The experimental examination also spends time and human resource higher than the numerical study. For the present research, the numerical investigation is opted to predict the mechanisms in the heat exchanger. For the pre-process, the numerical model is validated to increase the reliance of the numerical result. The numerical result can help to state the mechanisms of flow and heat transfer patterns in the test section. The knowledge of the heat transfer mechanism is significant factor to develop the heat transfer rate of the heat exchanger.

\section{PHYSICAL MODEL OF SQUARE DUCT INSERTED WITH DVO AND CASE STUDIES}

The square duct equipped with the DVO is illustrated as Figs. 1a and b for B20S0 and B20S10, respectively. The square duct height, $\mathrm{H}$, is equal to $0.05 \mathrm{~m}$. The hydraulic diameter of the square duct is equal to the square duct height, $\mathrm{Dh}_{\mathrm{h}}=\mathrm{H}$. The periodic length of the physical domain, $\mathrm{L}$, is also equal to the square duct height, $\mathrm{L}=\mathrm{H}$. The DVOs are arranged in the square duct with the spacing length, $\mathrm{P}$, of $0.05 \mathrm{~m}$ or $\mathrm{P} / \mathrm{H}$ $=1$. The flow attack angle of $30^{\circ}$ is selected for all configurations of the 
DVO. The parameters of the square duct inserted with the DVO are varied; DVO height (b) and distance between the outer border of the DVO and duct wall (s). Codes $\mathrm{B}$ and $\mathrm{S}$ represent $\mathrm{b} / \mathrm{H}$ and $\mathrm{s} / \mathrm{H}$ values, respectively. The flow direction of the square duct inserted with the DVO is also varied. The flow direction in positive $\mathrm{x}$-axis $(+\mathrm{x})$ is called "V-Downstream", while the opposite direction is called "V-Upstream". The V-Downstream and V-Upstream flow directions of the square duct inserted with the DVO represent with $\mathrm{D}$ and $\mathrm{U}$, respectively. For example, B20S10D is the square duct inserted with the DVO with $\mathrm{b} / \mathrm{H}$ $=0.20, \mathrm{~s} / \mathrm{H}=0.10$ and $\mathrm{V}$-Downstream arrangement. The square duct inserted with the DVO in $y-z$ plane is shown as Fig. 2. The case investigations of the square duct inserted with the DVO are concluded as Table 1 .
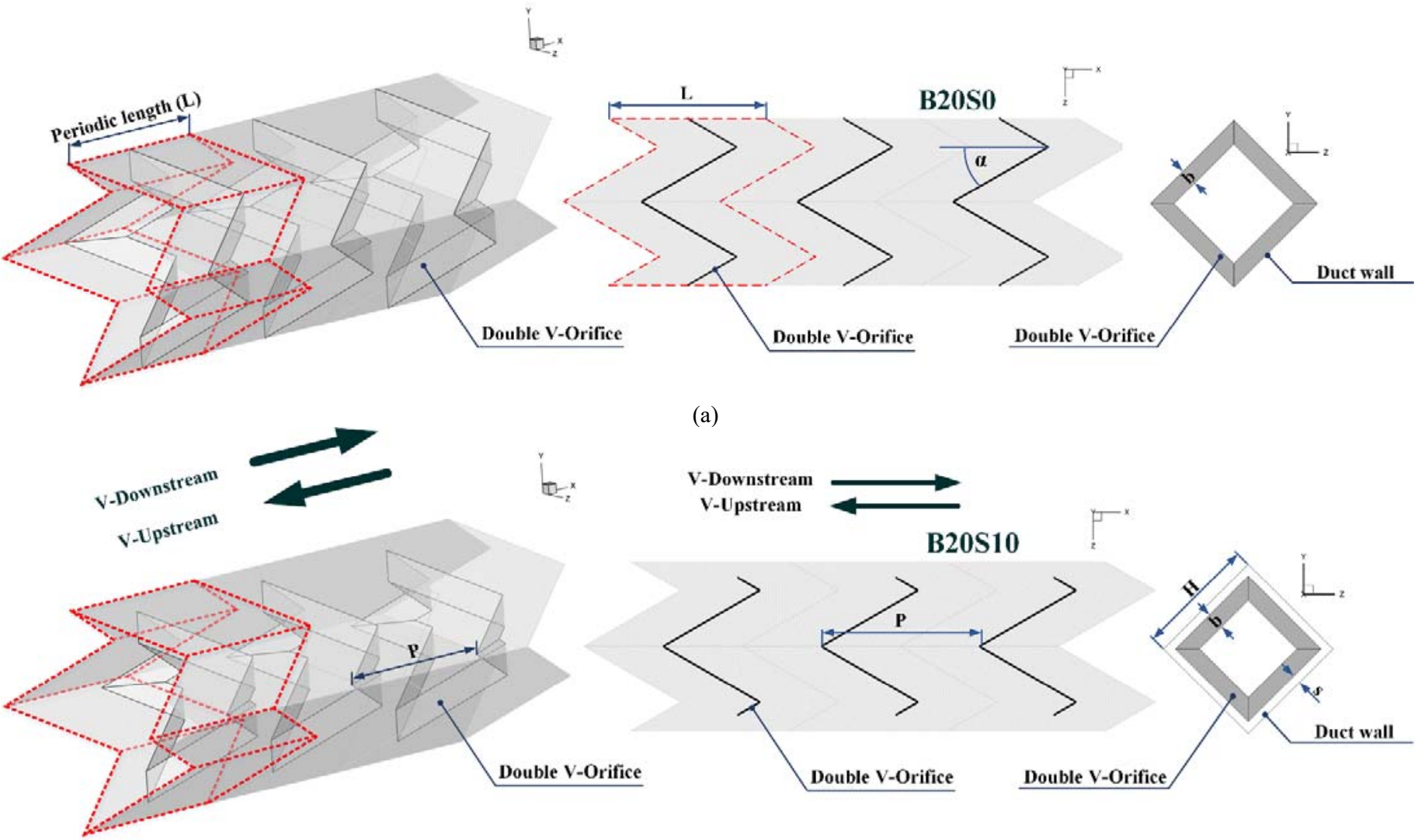

(a)

Fig. 1 Square duct inserted with the DVO for (a) B20S0 and (b)

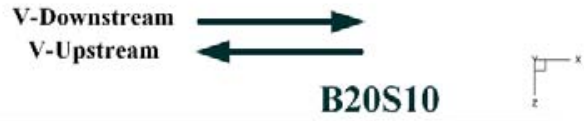

35<smiles>C1CCC1</smiles><smiles>C1C2CC12</smiles><smiles>C1C2CC3C1C23</smiles><smiles>C1=C2CC1C2</smiles><smiles></smiles>

B10<smiles>CC12CCC13CC23C</smiles><smiles>CC12C3CC1C2C3</smiles><smiles>CC12C3C4C5C3C1C5C42</smiles>

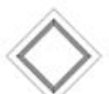

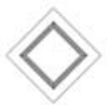

B15<smiles>CC12C3C4C5C3C1C5C42</smiles><smiles>CC12CC3C(C1)C32</smiles><smiles>CC12C3C4C5C3C1C5C42</smiles>

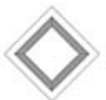

B20<smiles>C1=CC2=CC1=C2</smiles>
10

B25

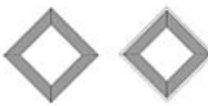

B30

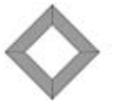

Fig. 2 Square duct inserted with the DVO in $y-z$ plane at various $s / H$ and $\mathrm{b} / \mathrm{H}$ values.

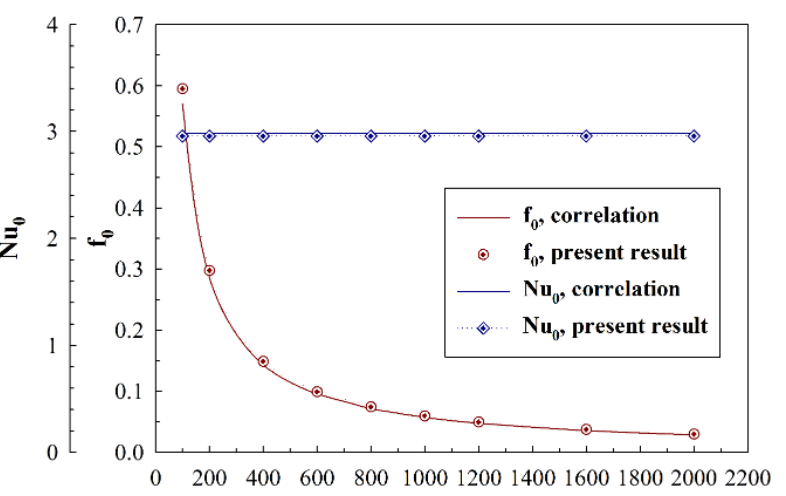

$\operatorname{Re}$

Fig. 3 Plain duct validation.

\section{MATHEMATICAL FOUNDATION, BOUNDARY CONDITION, ASSUMPTION AND NUMERICAL METHOD}

The forced convective heat transfer in the square duct inserted with the DVO is discussed. The unforced convection and radiation heat transfer in the square duct inserted with the DVO are disregarded. The air with the temperature around $300 \mathrm{~K}$ and Prandtl number of 0.707 is opted as the tested fluid. The tested fluid is agreed as incompressible flow because of the low velocity. Due to the variation of the fluid 
temperature is not higher than $10^{\circ} \mathrm{C}$, the thermal properties of the fluid are approved as constant values. The body force and viscous dissipation are ignored. The no slip wall condition is applied for all surfaces of the square duct inserted with the DVO. The fluid flow and heat transfer in the square duct inserted with the DVO are counted to be steady in three dimensions. The Reynolds number based on the hydraulic diameter of the square duct in the range $100-2000$ is analyzed. The periodic condition (Patankar et al. (1977)) on flow and heat transfer is adopted for the entrance and exit regions of the computational domain. The constant temperature around $310 \mathrm{~K}$ is applied for the duct walls. The constant heat flux around $0 \mathrm{~W} / \mathrm{m}^{2}$ is adopted for the DVO.

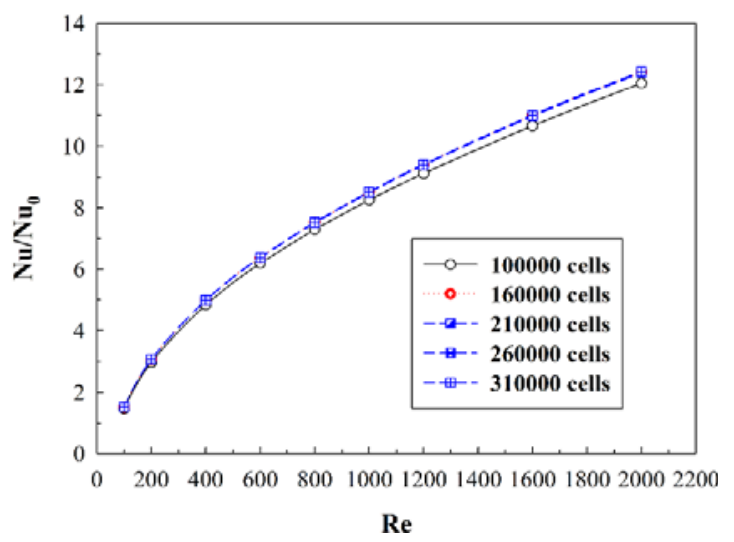

(a)

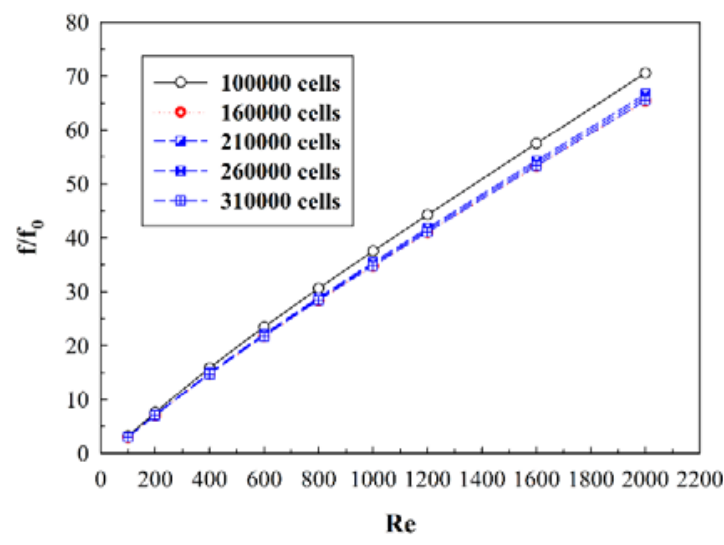

(b)

Fig. 4 Grid independence for (a) Nusselt number and (b) friction factor.

Table 1 Case investigations of the square duct inserted with the DVO.

\begin{tabular}{|c|c|c|c|}
\hline Code & V-Downstream arrangement & Code & V-Upstream arrangement \\
\hline B5S0D & $\mathrm{b} / \mathrm{H}=0.05, \mathrm{~s} / \mathrm{H}=0$ & B5S0U & $\mathrm{b} / \mathrm{H}=0.05, \mathrm{~s} / \mathrm{H}=0$ \\
\hline B5S5D & $\mathrm{b} / \mathrm{H}=0.05, \mathrm{~s} / \mathrm{H}=0.05$ & B5S5U & $\mathrm{b} / \mathrm{H}=0.05, \mathrm{~s} / \mathrm{H}=0.05$ \\
\hline B5S10D & $\mathrm{b} / \mathrm{H}=0.05, \mathrm{~s} / \mathrm{H}=0.10$ & B5S10U & $\mathrm{b} / \mathrm{H}=0.05, \mathrm{~s} / \mathrm{H}=0.10$, \\
\hline B5S15D & $\mathrm{b} / \mathrm{H}=0.05, \mathrm{~s} / \mathrm{H}=0.15$ & B5S15U & $\mathrm{b} / \mathrm{H}=0.05, \mathrm{~s} / \mathrm{H}=0.15$ \\
\hline B5S20D & $\mathrm{b} / \mathrm{H}=0.05, \mathrm{~s} / \mathrm{H}=0.20$ & B5S20U & $\mathrm{b} / \mathrm{H}=0.05, \mathrm{~s} / \mathrm{H}=0.20$ \\
\hline B5S25D & $\mathrm{b} / \mathrm{H}=0.05, \mathrm{~s} / \mathrm{H}=0.25$ & B5S25U & $\mathrm{b} / \mathrm{H}=0.05, \mathrm{~s} / \mathrm{H}=0.25$ \\
\hline B10S0D & $\mathrm{b} / \mathrm{H}=0.10, \mathrm{~s} / \mathrm{H}=0$ & B10S0U & $\mathrm{b} / \mathrm{H}=0.10, \mathrm{~s} / \mathrm{H}=0$ \\
\hline B10S5D & $\mathrm{b} / \mathrm{H}=0.10, \mathrm{~s} / \mathrm{H}=0.05$ & B10S5U & $\mathrm{b} / \mathrm{H}=0.10, \mathrm{~s} / \mathrm{H}=0.05$ \\
\hline B10S10D & $\mathrm{b} / \mathrm{H}=0.10, \mathrm{~s} / \mathrm{H}=0.10$ & B10S10U & $\mathrm{b} / \mathrm{H}=0.10, \mathrm{~s} / \mathrm{H}=0.10$ \\
\hline B10S15D & $\mathrm{b} / \mathrm{H}=0.10, \mathrm{~s} / \mathrm{H}=0.15$ & B10S15U & $\mathrm{b} / \mathrm{H}=0.10, \mathrm{~s} / \mathrm{H}=0.15$ \\
\hline B10S20D & $\mathrm{b} / \mathrm{H}=0.10, \mathrm{~s} / \mathrm{H}=0.20$ & B10S20U & $\mathrm{b} / \mathrm{H}=0.10, \mathrm{~s} / \mathrm{H}=0.20$ \\
\hline B15S0D & $\mathrm{b} / \mathrm{H}=0.15, \mathrm{~s} / \mathrm{H}=0$ & B15S0U & $\mathrm{b} / \mathrm{H}=0.15, \mathrm{~s} / \mathrm{H}=0$ \\
\hline B15S5D & $\mathrm{b} / \mathrm{H}=0.15, \mathrm{~s} / \mathrm{H}=0.05$ & B15S5U & $\mathrm{b} / \mathrm{H}=0.15, \mathrm{~s} / \mathrm{H}=0.05$ \\
\hline B15S10D & $\mathrm{b} / \mathrm{H}=0.15, \mathrm{~s} / \mathrm{H}=0.10$ & B15S10U & $\mathrm{b} / \mathrm{H}=0.15, \mathrm{~s} / \mathrm{H}=0.10$ \\
\hline B15S15D & $\mathrm{b} / \mathrm{H}=0.15, \mathrm{~s} / \mathrm{H}=0.15$ & B15S15U & $\mathrm{b} / \mathrm{H}=0.15, \mathrm{~s} / \mathrm{H}=0.15$ \\
\hline B20S0D & $\mathrm{b} / \mathrm{H}=0.20, \mathrm{~s} / \mathrm{H}=0$ & B20S0U & $\mathrm{b} / \mathrm{H}=0.20, \mathrm{~s} / \mathrm{H}=0$ \\
\hline B20S5D & $\mathrm{b} / \mathrm{H}=0.20, \mathrm{~s} / \mathrm{H}=0.05$ & B20S5U & $\mathrm{b} / \mathrm{H}=0.20, \mathrm{~s} / \mathrm{H}=0.05$ \\
\hline B20S10D & $\mathrm{b} / \mathrm{H}=0.20, \mathrm{~s} / \mathrm{H}=0.10$ & B20S10U & $\mathrm{b} / \mathrm{H}=0.20, \mathrm{~s} / \mathrm{H}=0.10$ \\
\hline B25S0D & $\mathrm{b} / \mathrm{H}=0.25, \mathrm{~s} / \mathrm{H}=0$ & B25S0U & $\mathrm{b} / \mathrm{H}=0.25, \mathrm{~s} / \mathrm{H}=0$ \\
\hline B25S5D & $\mathrm{b} / \mathrm{H}=0.25, \mathrm{~s} / \mathrm{H}=0.05$ & B25S5U & $\mathrm{b} / \mathrm{H}=0.25, \mathrm{~s} / \mathrm{H}=0.05$ \\
\hline B30S0D & $\mathrm{b} / \mathrm{H}=0.30, \mathrm{~s} / \mathrm{H}=0$ & B30S0U & $\mathrm{b} / \mathrm{H}=0.30, \mathrm{~s} / \mathrm{H}=0$ \\
\hline
\end{tabular}

The numerical model of the square duct inserted with the DVO is simulated by the commercial software (FLUENT). The major equations for the simulation procedure of the square duct inserted with the DVO are continuity, Navier-Stokes and energy equations as Equations 1, 2 and 3 , respectively. In the simulation process, the continuity and momentum equations are discretized by the power law scheme, while the energy equation is discretized with QUICK scheme. The numerical solutions are evaluated to be converged when the normalized residual values are less than $10^{-5}$ for all variables, but less than $10^{-9}$ only for the energy equation.

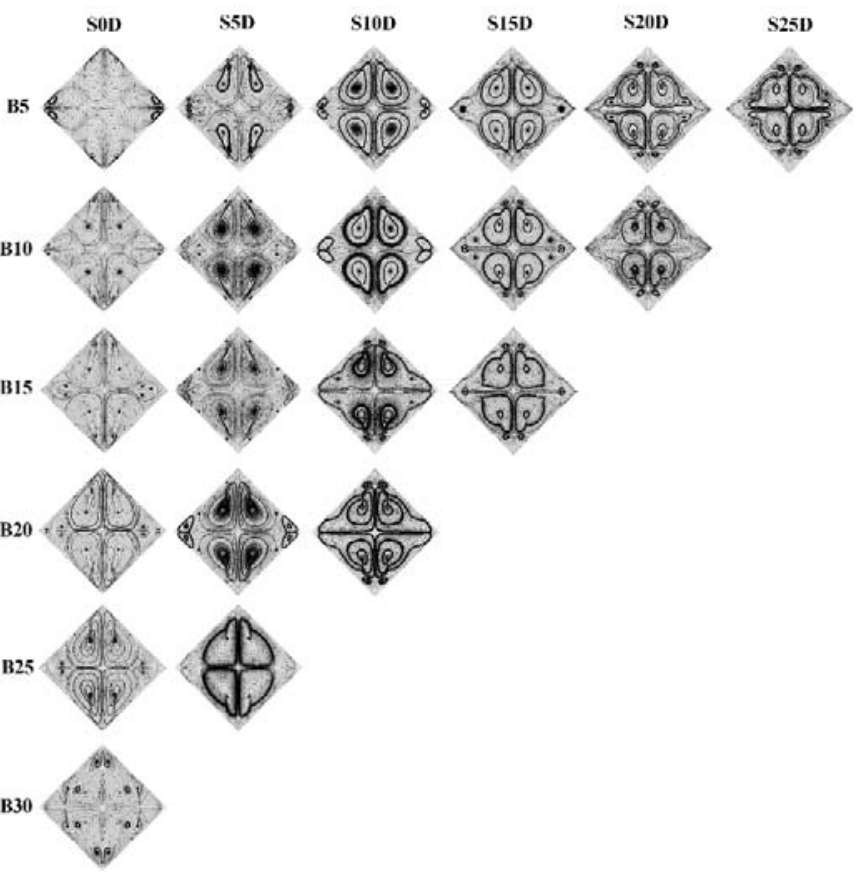

Fig. 5 Streamline plot in $y-z$ plane of the square duct inserted with the DVO at various cases for V-Downstream arrangement and $\operatorname{Re}=600$
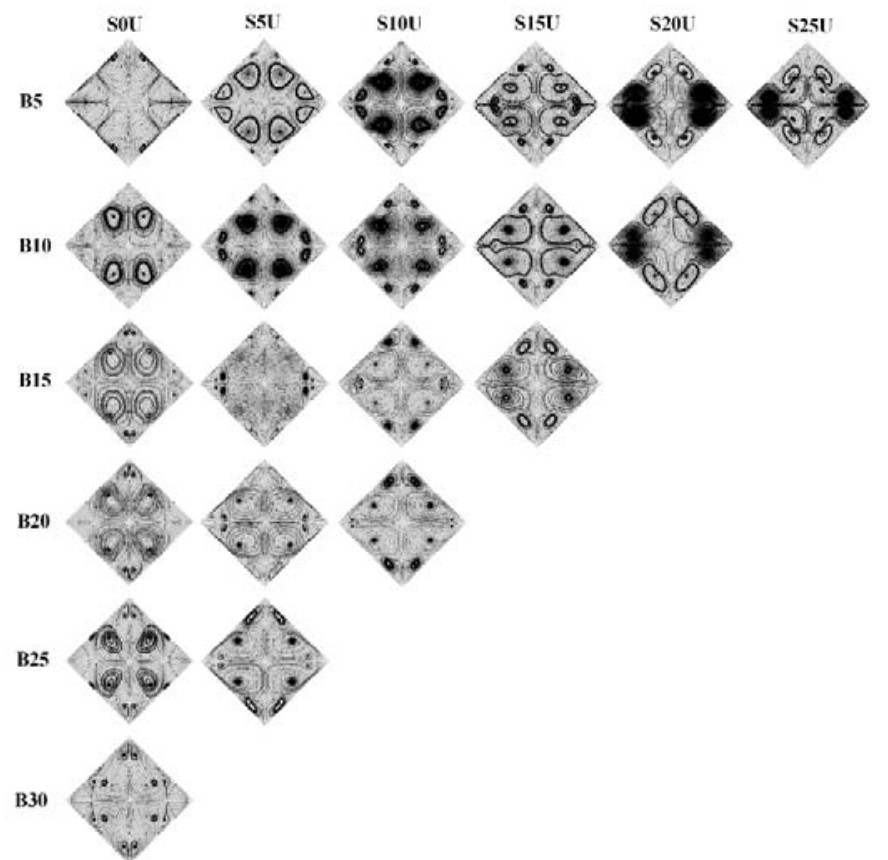

Fig. 6 Streamline plot in $y-z$ plane of the square duct inserted with the DVO at various cases for V-Upstream arrangement and $\operatorname{Re}=600$. 
Continuity equation:

$$
\frac{\partial}{\partial x_{i}}\left(\rho u_{i}\right)=0
$$

Momentum equation:

$$
\frac{\partial\left(\rho u_{i} u_{j}\right)}{\partial x_{j}}=-\frac{\partial p}{\partial x_{i}}+\frac{\partial}{\partial x_{j}}\left[\mu\left(\frac{\partial u_{i}}{\partial x_{j}}+\frac{\partial u_{j}}{\partial x_{i}}\right)\right]
$$

Energy equation:

$$
\frac{\partial}{\partial x_{i}}\left(\rho u_{i} T\right)=\frac{\partial}{\partial x_{j}}\left(\Gamma \frac{\partial T}{\partial x_{j}}\right)
$$

where, $\Gamma$ is the thermal diffusivity and is written as follows:

$\Gamma=\frac{\mu}{\operatorname{Pr}}$

The dimensionless variable of the fluid velocity in the square duct inserted with the DVO is Reynolds number. The Reynolds number is computed as Equation 5.

$\operatorname{Re}=\frac{\rho \bar{u} D_{h}}{\mu}$

The pressure loss of the square duct inserted with the DVO is also concluded with the dimensionless variable, friction factor. The friction factor can be calculated from Equation 6 .

$$
f=\frac{(\Delta p / L) D_{h}}{\frac{1}{2} \rho \bar{u}^{2}}
$$

The ability of heat transfer in the square duct inserted with the DVO is summarized by local Nusselt number and average Nusselt number (Promvonge et al. (2010)) as Equations 7 and 8, respectively.

$$
\begin{aligned}
& N u_{x}=\frac{h_{x} D_{h}}{k} \\
& N u=\frac{1}{L} \int N u_{x} \partial x
\end{aligned}
$$

The thermal enhancement factor or TEF (Promvonge et al. (2010)) of the square duct inserted with the DVO is considered at similar pumping power as Equation 9. The TEF is defined as the ratio between the heat transfer coefficient of the square duct inserted with the DVO, $\mathrm{h}$, and the heat transfer coefficient of the plain duct, $\mathrm{h}_{0}$.

$$
T E F=\left.\frac{h}{h_{0}}\right|_{p p}=\left.\frac{N u}{N u_{0}}\right|_{p p}=\left(\frac{N u}{N u_{0}}\right) /\left(\frac{f}{f_{0}}\right)^{1 / 3}
$$

The subscript zero means the value of the plain duct.

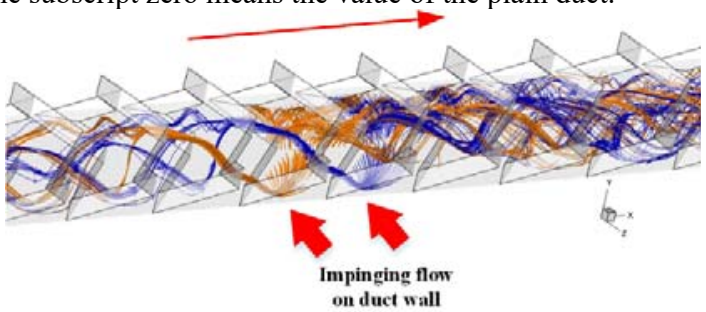

(a)

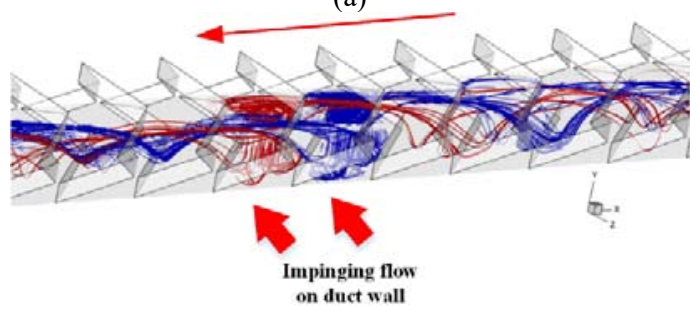

(b)

Fig. 7 Longitudinal vortex flow of the square duct inserted with the DVO for (a) B20S0D and (b) B20S0U at Re $=800$.

\section{NUMERICAL VALIDATION}

The numerical validation is an important process for the numerical investigation. The model validation helps to increase the reliance of the numerical result. The validations of the computational domain for the square duct inserted with the DVO consist 1. Plain duct validation and 2. Grid independence. For the plain duct validation, the comparison between the numerical results with the results from the correlations (Cengel and Ghajar (2015)) is conducted. The deviations between the present results and the values from the correlations both Nusselt number and friction factor are not higher than $\pm 10 \%$. The plain duct validations of the present work are depicted as Fig. 3.

The purpose for the grid check is to find appropriate number of grid cell. The suitable grid cell can help to conserve computational resource and time for simulation. For the smooth duct, the variation of grid cells in the range $80000-310000$ has no effect for both Nusselt number and friction factor for all Reynolds numbers. The models of the square duct inserted with the DVO with various grid cells; 100000, $160000,210000,260000$ and 310000 , are compared. The heat transfer and pressure loss in the square duct inserted with the DVO for the B20S0D are checked. The trends of the Nusselt number and friction factor for the square duct inserted with the DVO with grid cell around 160000 differs from the trends of the numerical model with grid cell higher than 160000 around $\pm 3 \%$, as Fig. 4 . From the pre-result, the grid cell around 160000 is opted for all cases of the computational domain for the square duct inserted with the DVO.

\section{NUMERICAL RESULT AND DISCUSSION}

\subsection{Flow structure}

The flow description in the square duct inserted with the DVO is stated in this section. The streamline plot in transverse planes is created to check the generation of the vortex flow in the square duct inserted with the DVO. The streamline plot in transverse planes of the square duct inserted with the DVO is reported as Figs. 5 and 6 for V-Downstream and V-Upstream arrangements, respectively. In all planes, the vortex flow, which is built by the DVO, is seen. The general configuration of the vortex flow includes four main vortex cores and small vortices at the corners of the square duct. The symmetry structure of the flow at the left-right parts and upper-lower parts is seen due to the symmetry shape of the DVO. Seeing at the lower pair of the vortex core, the VDownstream direction produces the counter-rotating flow with common-flow-down, while the V-Upstream direction forms the counter-rotating flow with common-flow-up. The main flow pattern in the square duct inserted with the DVO slightly change when changing the $\mathrm{s} / \mathrm{H}$ value. The vortex flow affects for the variation of the boundary layer in the square duct inserted with the DVO. The thermal boundary layer in the square duct inserted with the DVO is annoyed by the vortex flow. Moreover, the vortex flow in the square duct inserted with the DVO affects for the fluid temperature distribution. The turbulent fluid mixing always found when installed the vortex generator in the heat exchanger device. The temperature distribution and thermal boundary layer change in the square duct inserted with the DVO can be seen in the next part, heat transfer profile.

The vortex core of the square duct inserted with the DVO slightly differ when varied the $\mathrm{b} / \mathrm{H}$ values. The size of the vortices at the corner of the square duct inserted with the DVO obviously increases when augmenting $\mathrm{s} / \mathrm{H}$ values, especially, at $\mathrm{s} / \mathrm{H}>0.05$.

The small vortices at the corner of the square duct inserted with the DVO have opposite rotation from the main flow. The improvement of the vortices size may affect for the reduction of the main vortex strength and the variation of the local heat transfer coefficient on the duct wall. The differentiation of the flow profile in the square duct inserted with the DVO influences for the increment or decrease of the heat transfer rate and pressure loss. 


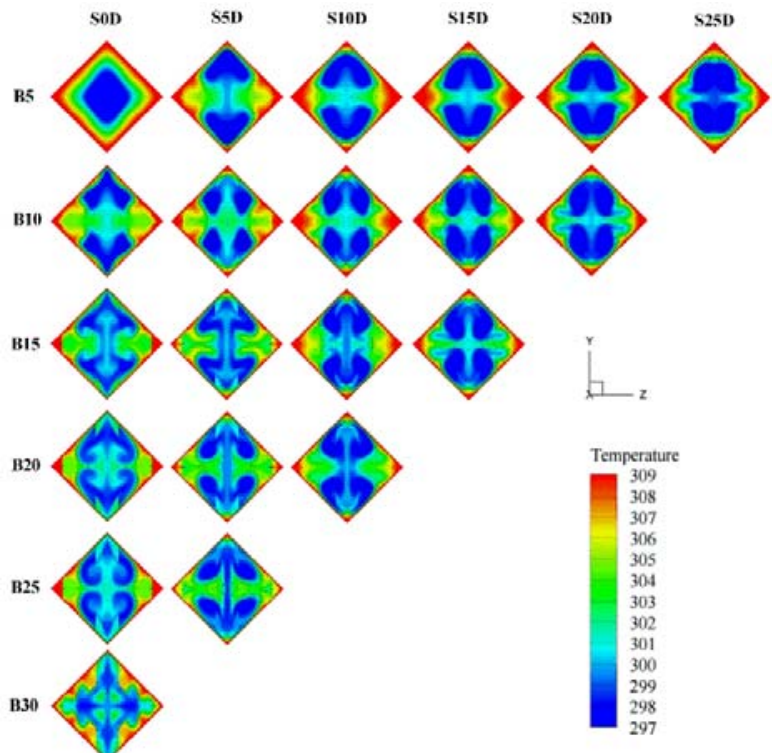

Fig. 8 Fluid temperature contour in $y-z$ plane of the square duct inserted with the DVO at various cases for V-Downstream arrangement and $\mathrm{Re}=600$.

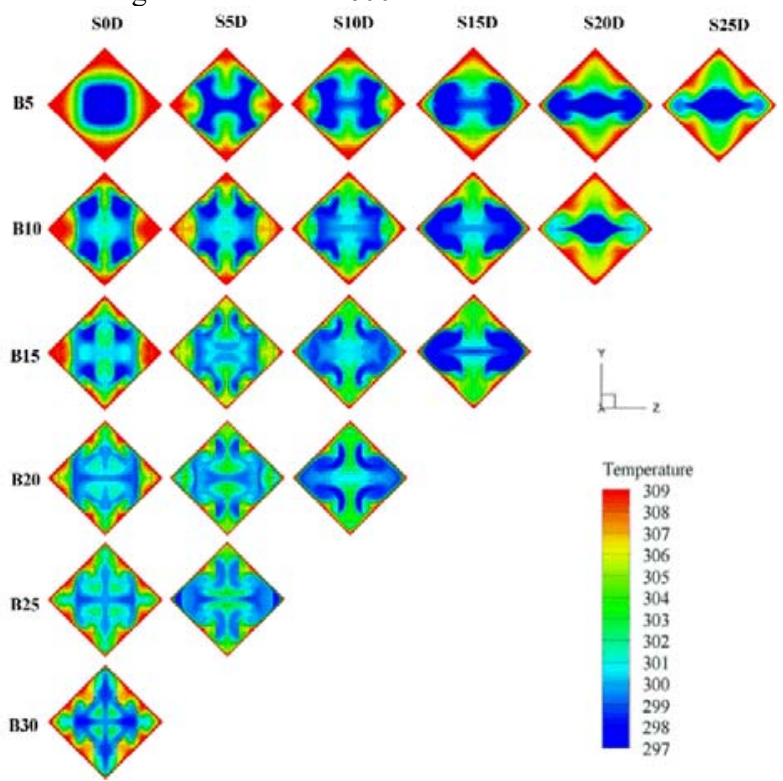

Fig. 9 Fluid temperature contour in $y-z$ plane of the square duct inserted with the DVO at various cases for V-Upstream arrangement and $\mathrm{Re}=600$.

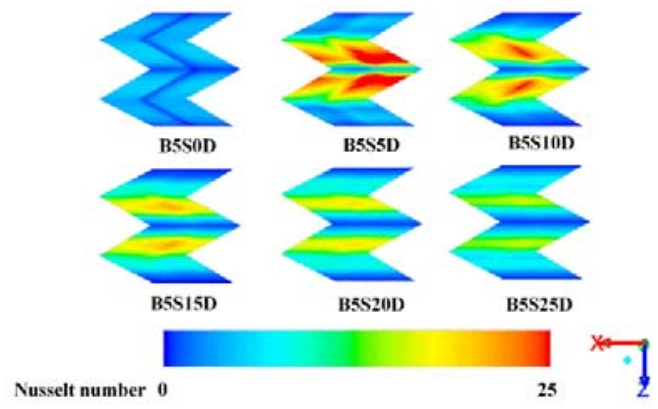

Fig. 10 Local Nusselt number contour of the square duct inserted with the DVO at B5D and $\mathrm{Re}=600$.

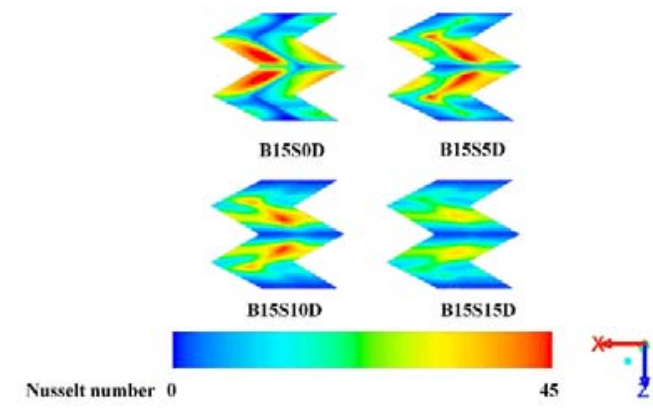

Fig. 11 Local Nusselt number contour of the square duct inserted with the DVO at $\mathrm{B} 15 \mathrm{D}$ and $\mathrm{Re}=600$.

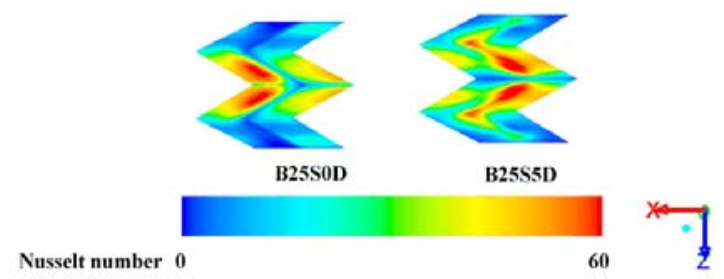

Fig. 12 Local Nusselt number contour of the square duct inserted with the $\mathrm{DVO}$ at $\mathrm{B} 25 \mathrm{D}$ and $\mathrm{Re}=600$.

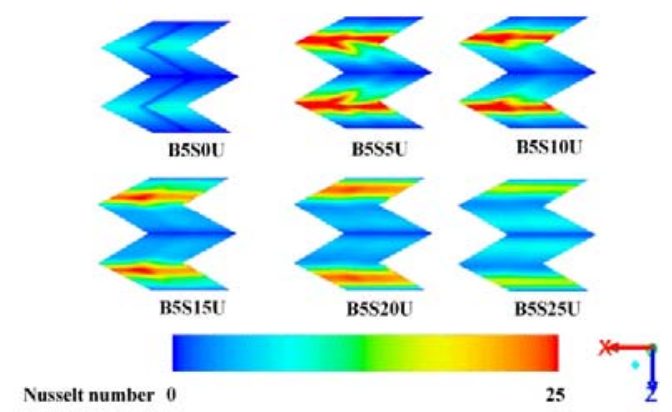

Fig. 13 Local Nusselt number contour of the square duct inserted with the DVO at B5U and $\mathrm{Re}=600$.

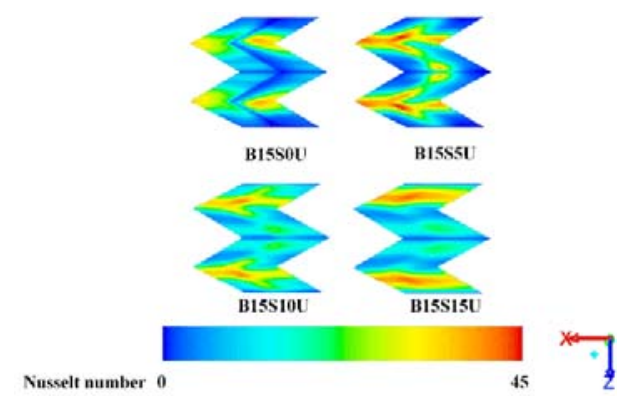

Fig. 14 Local Nusselt number contour of the square duct inserted with the DVO at $\mathrm{B} 15 \mathrm{U}$ and $\mathrm{Re}=600$.

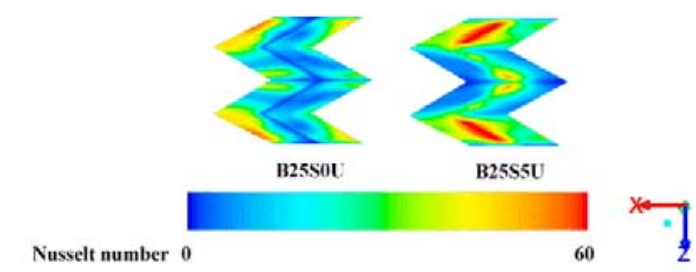

Fig. 15 Local Nusselt number contour of the square duct inserted with the DVO at B25U and $\mathrm{Re}=600$. 
The longitudinal fluid flow in the square duct inserted with the DVO at $\operatorname{Re}=800$ is plotted as Figs. 7a and b for B20S0D and B20S0U, respectively. For both cases, the impingement of the air on the duct wall of the square duct inserted with the DVO is seen. The impinging of the air on the heat transfer surface for the square duct inserted with the
DVO is significant factor for thermal boundary layer disturbance. The strength of the impinging fluid in the square duct can be increased or decreased when differed the $\mathrm{s} / \mathrm{H}$ and $\mathrm{b} / \mathrm{H}$ values. The strength of the fluid impingement directly affects for the ability of heat transfer in the square duct inserted with the DVO.

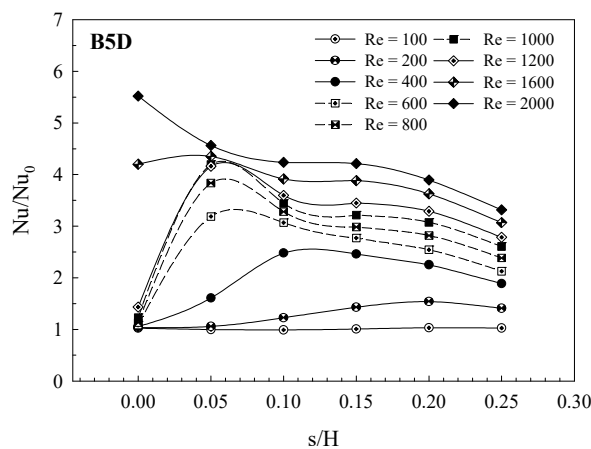

(a)

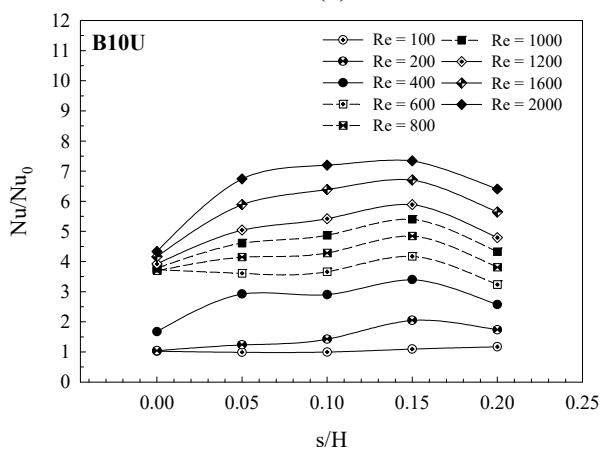

(d)

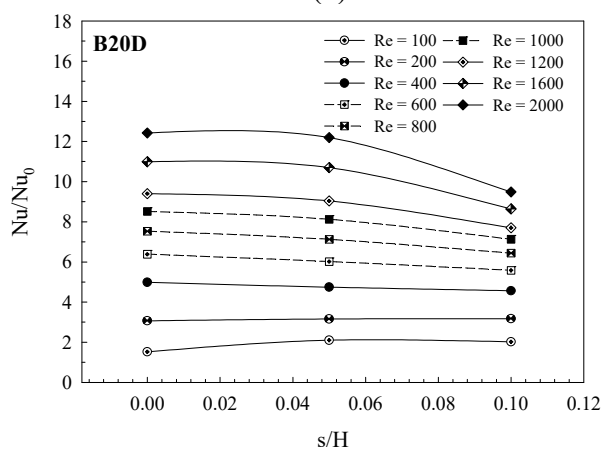

(g)

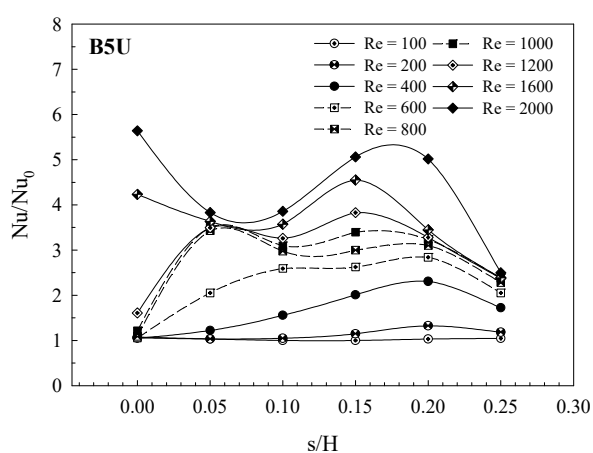

(b)

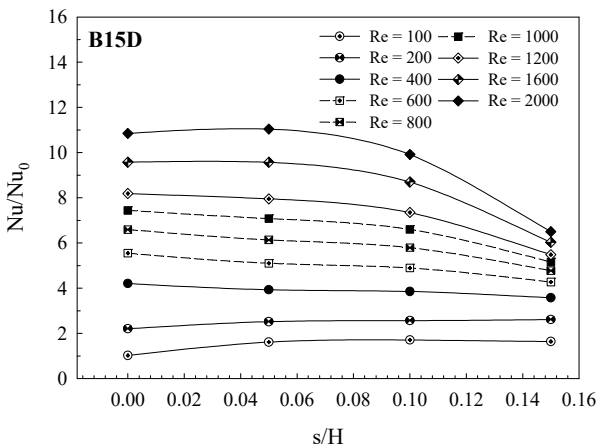

(e)

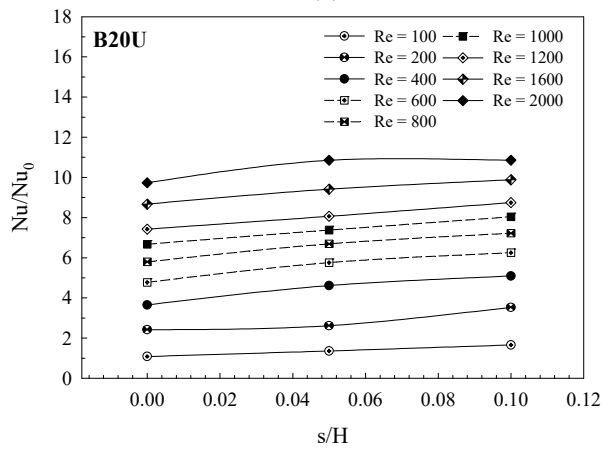

(h)

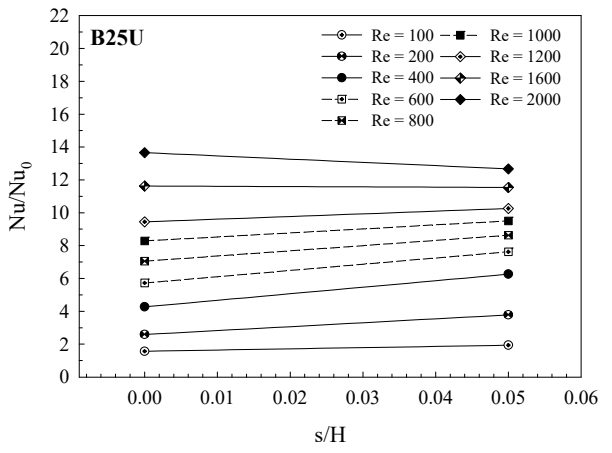

(j)

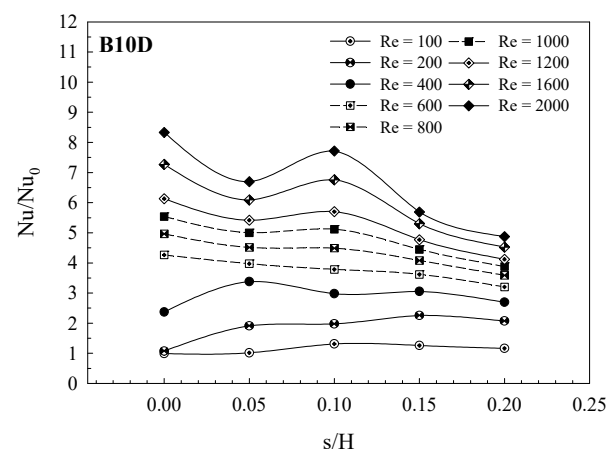

(c)

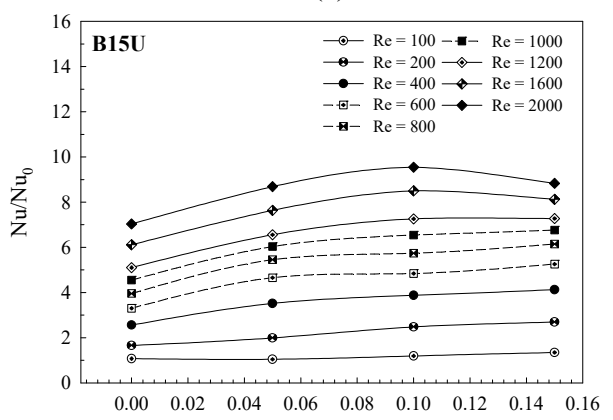

$\mathrm{s} / \mathrm{H}$

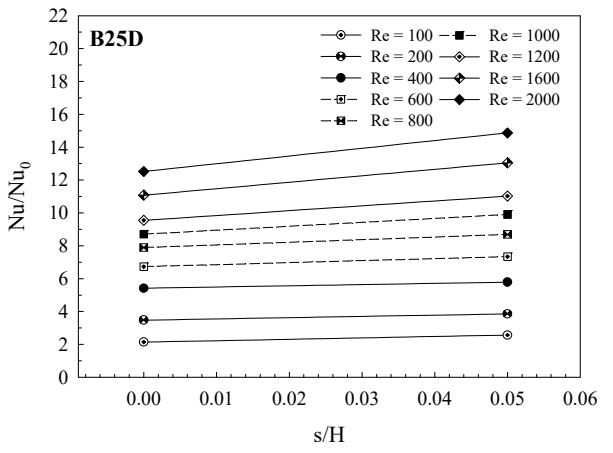

(i)

Fig. 16 Nu/Nuo vs s/H for (a) B5D, (b) B5U, (c) B10D, (d) B10U, (e) B15D, (f) B15U, (g) B20D, (h) B20U, (i) B25D and (j) B25U. 


\subsection{Heat transfer profile}

The variations of fluid temperature, thermal boundary layer and local Nusselt number of the square duct inserted with the DVO are considered in this part. The fluid temperature distribution in y-z plane for the square duct inserted with the DVO is plotted as Figs. 8 and 9 for V-Downstream and V-Upstream cases, respectively, at $\mathrm{Re}=600$.

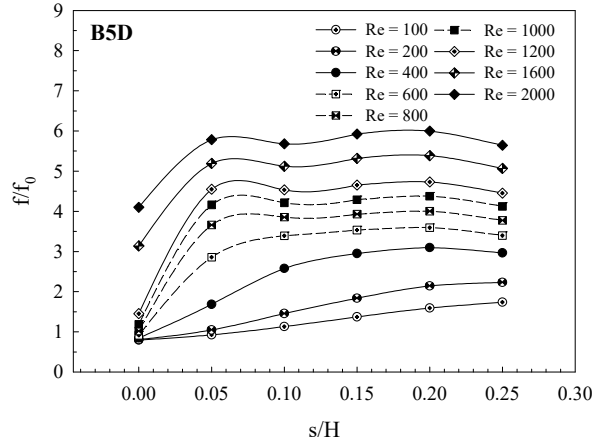

(a)

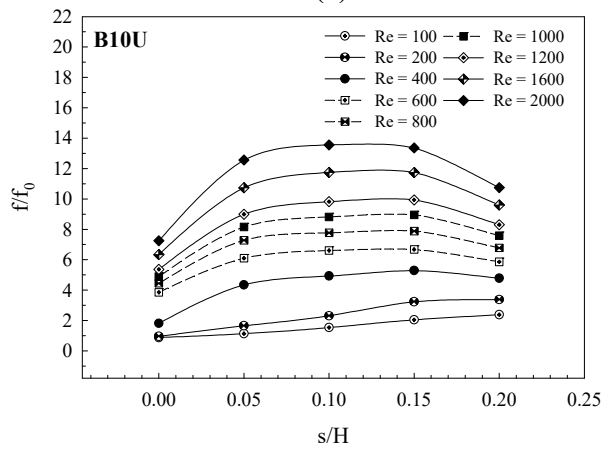

(d)

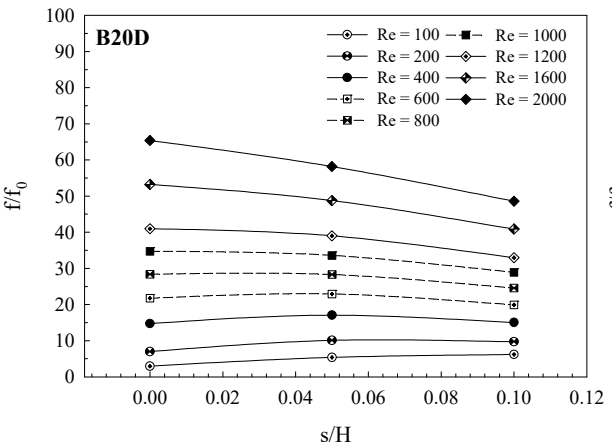

(g)

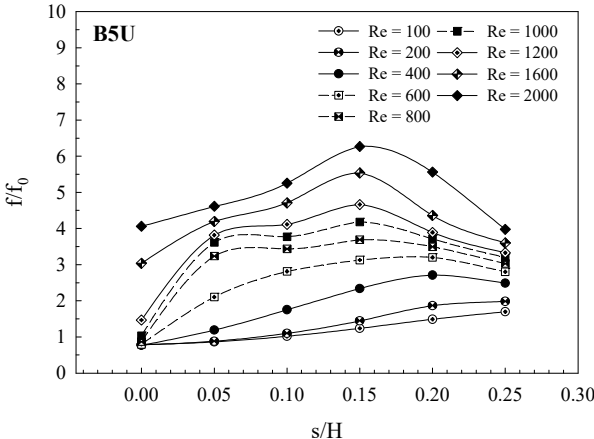

(b)

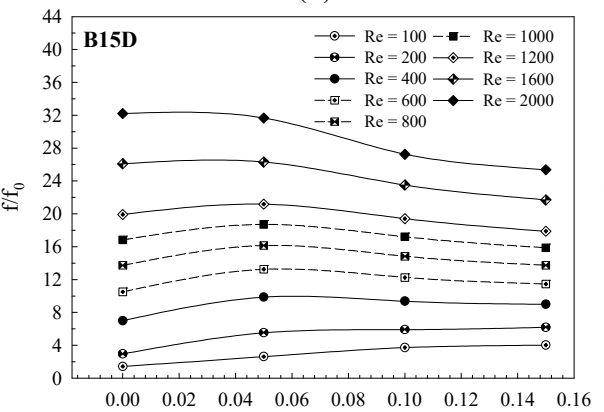

$\mathrm{s} / \mathrm{H}$

(e)

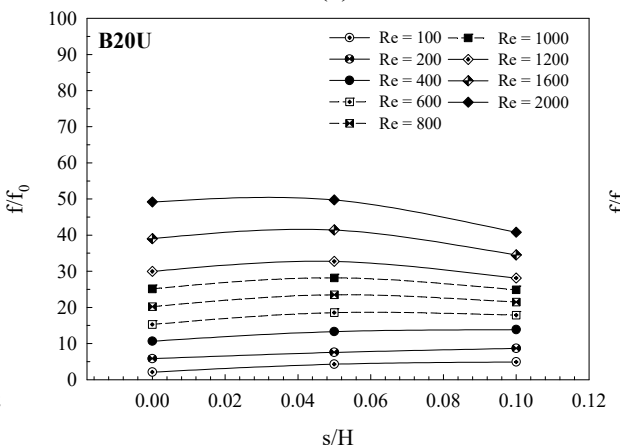

(h)

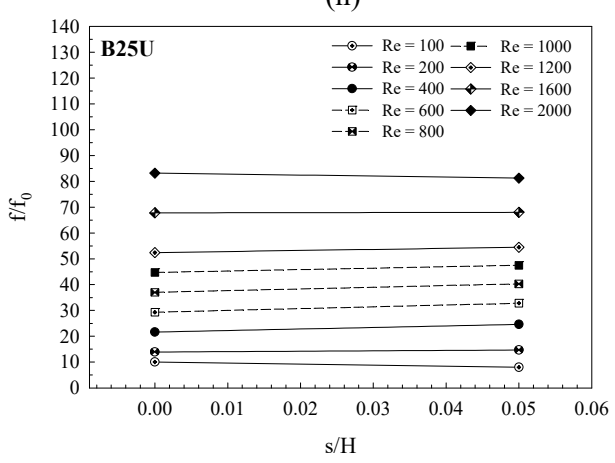

(j)

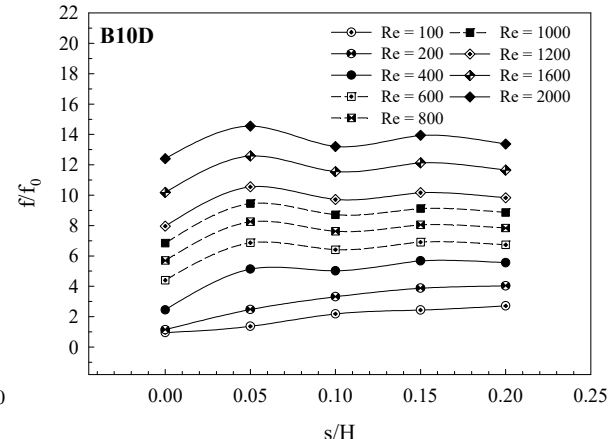

(c)

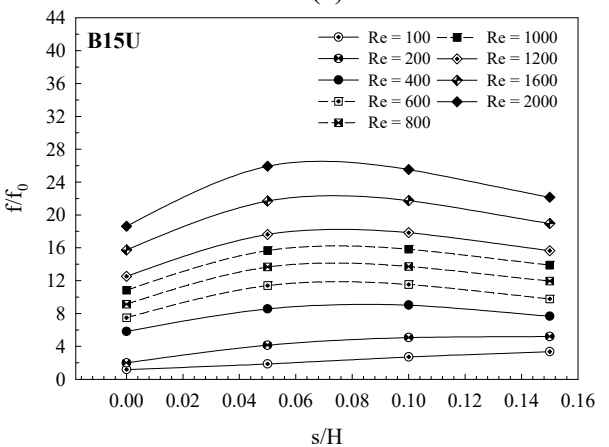

(f)

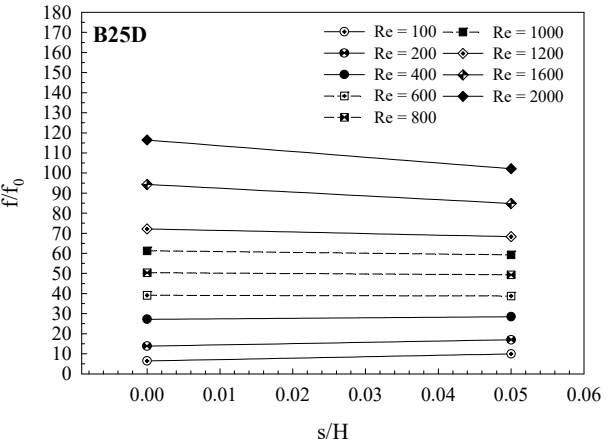

(i)

Fig. $17 \mathrm{f} / \mathrm{f}_{0}$ vs s/H for (a) B5D, (b) B5U, (c) B10D, (d) B10U, (e) B15D, (f) B15U, (g) B20D, (h) B20U, (i) B25D and (j) B25U. 


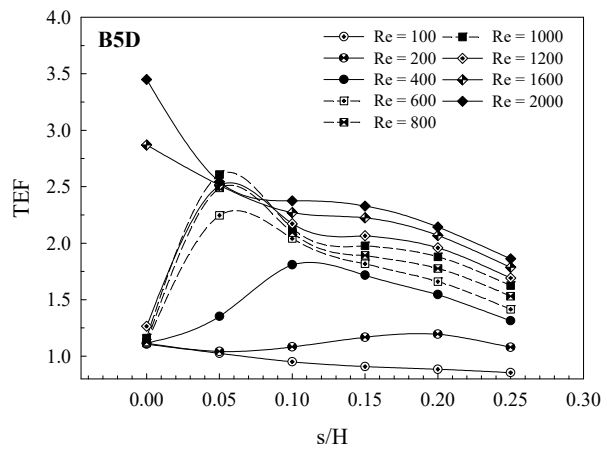

(a)

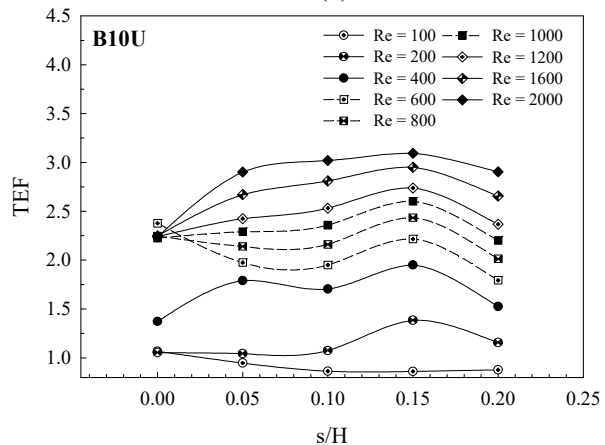

(d)

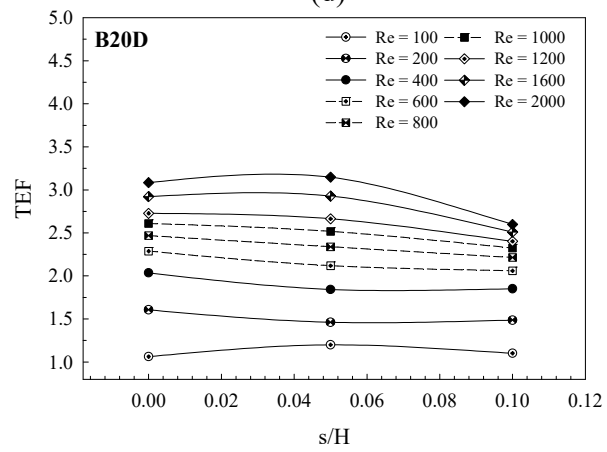

(g)

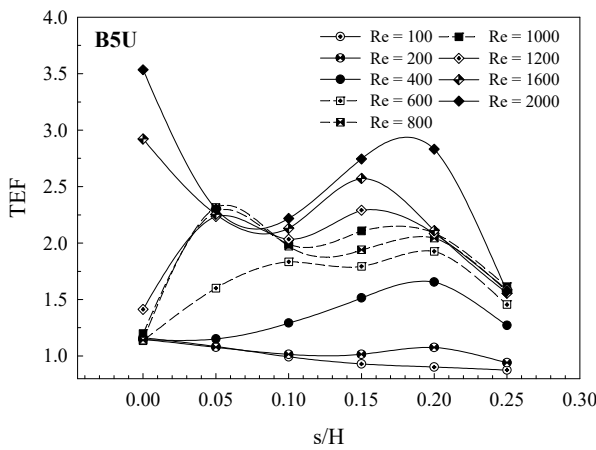

(b)

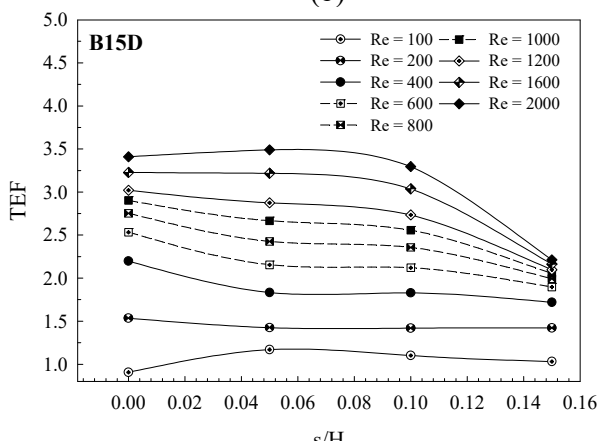

(e)

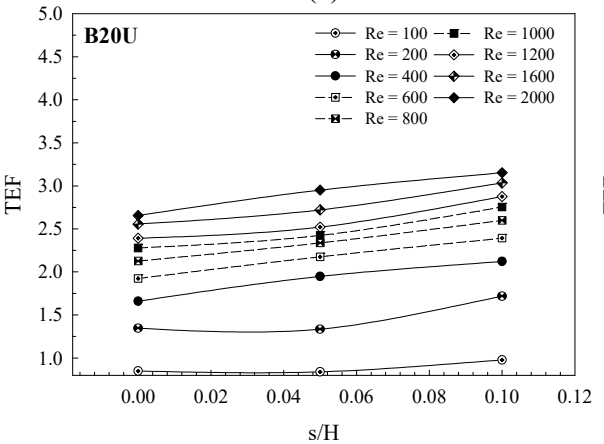

(h)

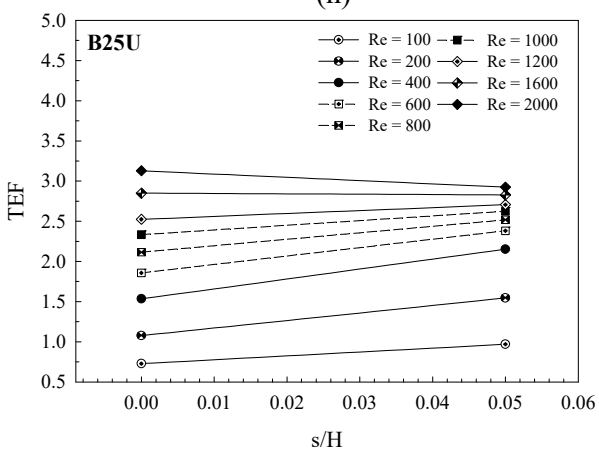

(j)

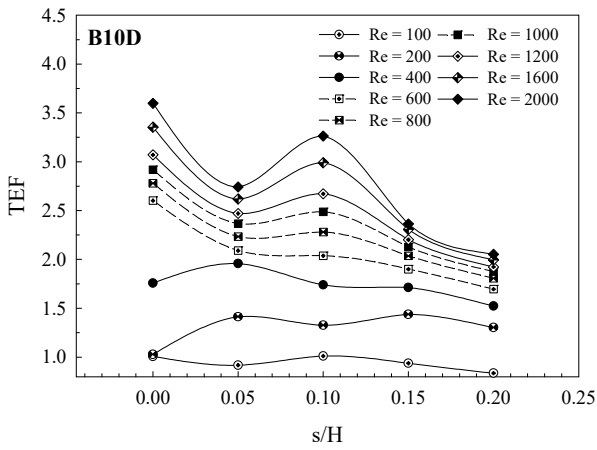

(c)

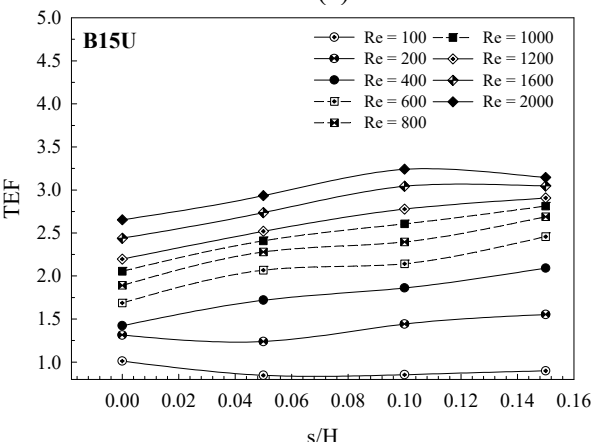

(f)

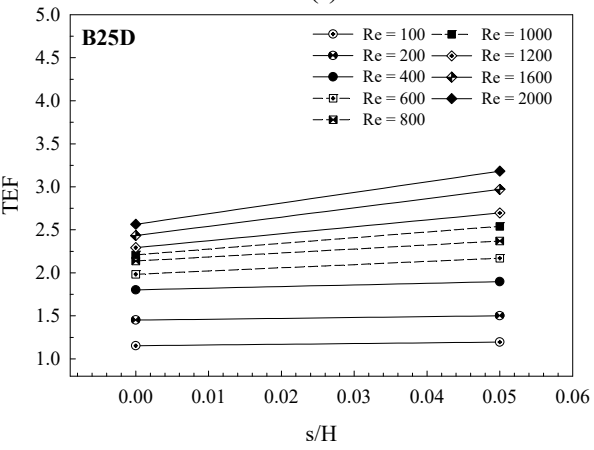

(i)

Fig. 18 TEF vs s/H for (a) B5D, (b) B5U, (c) B10D, (d) B10U, (e) B15D, (f) B15U, (g) B20D, (h) B20U, (i) B25D and (j) B25U.

The disruption of the thermal boundary layer in the square duct inserted with the DVO is detected along the heating duct for all examined cases. The disturbance layer can be considered by the thickness of the red contour. The high heat transfer rate is found in all walls of the square duct inserted with the DVO, while the four corners of the square duct are detected in reverse trend.

The local Nusselt number distribution on the duct walls of the square duct inserted with the DVO is plotted as Figs. 10, 11, and 12 for B5D, B15D and B25D, respectively, and as Figs. 13, 14 and 15, for $\mathrm{B} 5 \mathrm{U}, \mathrm{B} 15 \mathrm{U}$ and $\mathrm{B} 25 \mathrm{U}$, respectively, at $\mathrm{Re}=600$. In general, the poor heat transfer rate in the square duct inserted with the DVO is clearly found at four corners of the duct. At B5D and B5U, the S5 gives the best heat transfer ability, while the $\mathrm{S} 0$ provides the opposite result. The local Nusselt number for the square duct inserted with the DVO is not in similar pattern due to the variations of the flow structure when varied the $\mathrm{s} / \mathrm{H}, \mathrm{b} / \mathrm{H}$ and flow direction.

\subsection{Performance report}

In this section, the heat transfer, pressure loss and thermal efficiency of the square duct inserted with the DVO are shown with the 
dimensionless variables; Nusselt number $(\mathrm{Nu})$, friction factor (f) and thermal enhancement factor (TEF), respectively. The variations of the $\mathrm{Nu} / \mathrm{Nu}_{0}$ versus $\mathrm{s} / \mathrm{H}$ at various Re are plotted as Figs. 16a, b, c, d, e, f, g, $\mathrm{h}$, i and j, respectively, for B5D, B5U, B10D, B10U, B15D, B15U, B20D, B20U, B25D and B25U. In almost cases, the $\mathrm{Nu} / \mathrm{Nu}_{0}$ increases when augmenting the Reynolds number. In the range investigates, the $\mathrm{Nu} / \mathrm{Nu}_{0}$ is around $1.00-5.52,1.00-8.33,1.02-11.04,1.52-12.42$, $2.14-14.87,2.56-13.23,1.00-5.64,1.00-7.34,1.04-9.54,1.09-$ $10.85,1.57-13.66$ and $1.97-14.80$ times above the plain duct, respectively, for $\mathrm{B} 5 \mathrm{D}, \mathrm{B} 10 \mathrm{D}, \mathrm{B} 15 \mathrm{D}, \mathrm{B} 20 \mathrm{D}, \mathrm{B} 25 \mathrm{D}, \mathrm{B} 30 \mathrm{D}, \mathrm{B} 5 \mathrm{U}, \mathrm{B} 10 \mathrm{U}$, $\mathrm{B} 15 \mathrm{U}, \mathrm{B} 20 \mathrm{U}, \mathrm{B} 25 \mathrm{U}$ and $\mathrm{B} 30 \mathrm{U}$. For the $\mathrm{B} 5$, the high heat transfer rate is found at $\mathrm{s} / \mathrm{H}$ around $0-0.15$ for $\mathrm{V}$-Downstream, while around $0.10-$ 0.20 for V-Upstream. The great Nusselt number is detected at $\mathrm{s} / \mathrm{H}$ in the range $0-0.10$ and $0.10-0.15$, respectively, for $\mathrm{B} 10 \mathrm{D}$ and $\mathrm{B} 10 \mathrm{U}$. The $\mathrm{s} / \mathrm{H}=0-0.05$ and $0.10-0.15$ of the ducts inserted with the DVO performs the best heat transfer rate for $\mathrm{B} 15 \mathrm{D}$ and $\mathrm{B} 15 \mathrm{U}$, respectively. The high heat transfer rate is found at $\mathrm{s} / \mathrm{H}=0-0.05$ and $0.05-0.10$ for $\mathrm{B} 20 \mathrm{D}$ and B20U, respectively. For the B25, the variation of the $\mathrm{s} / \mathrm{H}$ slightly effects for heat transfer rate of both arrangements.

The relation of the $\mathrm{f} / \mathrm{f}_{0}$ with $\mathrm{s} / \mathrm{H}$ for $\mathrm{B} 5, \mathrm{~B} 10, \mathrm{~B} 15, \mathrm{~B} 20, \mathrm{~B} 25$ and $\mathrm{B} 30$ in the square duct inserted with the DVO is plotted as Figs. 17a, b, $\mathrm{c}, \mathrm{d}$, e and $\mathrm{f}$, respectively. The $\mathrm{f} / \mathrm{f}_{0}$ in the square duct inserted with the DVO grows when increasing the Reynolds number in all cases. The highest friction loss in the square duct inserted with the DVO is seen at S20, S5, S0, S0, S0, S15, S10, S5, S5 and S0 for B5D, B10D, B15D, $\mathrm{B} 20 \mathrm{D}, \mathrm{B} 25 \mathrm{D}, \mathrm{B} 5 \mathrm{U}, \mathrm{B} 10 \mathrm{U}, \mathrm{B} 15 \mathrm{U}, \mathrm{B} 20 \mathrm{U}$ and B25U, respectively, when considering at $\operatorname{Re}=2000$. The $\mathrm{f} / \mathrm{f}_{0}$ of the square duct inserted with the DVO is around $1.00-6.00,1.00-14.55,1.44-32.21,2.94-65.37$, $6.42-116.45,12.85-180.07,1.00-6.27,1.00-13.55,1.18-25.94$, $2.94-49.75,8.01-83.21$ and $10.72-190.21$ for B5D, B10D, B15D, $\mathrm{B} 20 \mathrm{D}, \mathrm{B} 25 \mathrm{D}, \mathrm{B} 30 \mathrm{D}, \mathrm{B} 5 \mathrm{U}, \mathrm{B} 10 \mathrm{U}, \mathrm{B} 15 \mathrm{U}, \mathrm{B} 20 \mathrm{U}, \mathrm{B} 25 \mathrm{U}$ and $\mathrm{B} 30 \mathrm{U}$, respectively.

Figs. 18a, b, c, d, e and $\mathrm{f}$ report the variation of the TEF with the $\mathrm{s} / \mathrm{H}$ for the square duct inserted with the DVO of B5, B10, B15, B20, $\mathrm{B} 25$ and $\mathrm{B} 30$, respectively. The maximum TEF of the square duct inserted with the DVO for B5D, B10D, B15D, B20D, B25D, B5U, $\mathrm{B} 10 \mathrm{U}, \mathrm{B} 15 \mathrm{U}, \mathrm{B} 20 \mathrm{U}$ and $\mathrm{B} 25 \mathrm{U}$ is detected at S0, S0, S5, S5, S5, S0, $\mathrm{S} 15, \mathrm{~S} 10, \mathrm{~S} 10$ and S0, respectively, at $\mathrm{Re}=2000$. The highest TEF of the square duct inserted with the DVO is around 3.45, 3.60, 3.49, 3.15, $3.18,2.34,3.54,3.09,3.24,3.15,3.13$ and 2.57 , respectively, for B5D, B10D, B15D, B20D, B25D, B30D, B5U, B10U, B15U, B20U, B25U and $\mathrm{B} 30 \mathrm{U}$.

\section{CONCLUSION}

The flow and heat transfer mechanisms in the square duct inserted with the DVO with various $\mathrm{s} / \mathrm{H}, \mathrm{b} / \mathrm{H}$ and Re values are numerically studied. The effect of $\mathrm{s} / \mathrm{H}$ and $\mathrm{b} / \mathrm{H}$ on flow and heat transfer for the square duct inserted with the DVO are analyzed for the Reynolds number around $100-2000$. The outcomes from the present investigation can conclude as follows;

The DVO in the square duct heat exchanger can produce the vortex flow through the test section in all cases. The vortex flow disturbs the thermal boundary layer that the cause for heat transfer and performance developments. The vortex flow in the heat exchanger duct also helps a better fluid mixing.

The maximum heat transfer rate of the heat exchanger square duct inserted with the DVO is about 14.80 times above the plain duct, while the optimal thermal enhancement factor is found to be about 3.60.

For suggestion, the gap spacing between the outer edges of the DVO and the square duct should be around $0-10 \%$ when considered the TEF value.

The installation, manufacturing and maintenance of the heat exchanger square duct inserted with the DVO are more stable and convenience than the rib or baffle type vortex generator. The heat exchanger square duct inserted the DVO gives closely value of thermal enhancement factor when compared with rib and baffle vortex generators (Jedsadaratanachai et al. (2015), Jedsadaratanachai and Boonloi (2014), Jedsadaratanachai et al. (2011), Promvonge et al. (2012), Promvonge et al. (2010)).

\section{ACKNOWLEDGMENTS}

The authors would like to acknowledge Assoc. Prof. Dr. Pongjet Promvonge for suggestions.

This research was funded by College of Industrial Technology, King Mongkut's University of Technology North Bangkok (Grant No. ResCIT0258/2020).

\section{NOMENCLATURE}

b DVO height, $\mathrm{m}$

$\mathrm{D}_{\mathrm{h}} \quad$ hydraulic diameter of duct, $\mathrm{m}$

$\mathrm{f}$ friction factor

$\mathrm{H}$ duct height, $\mathrm{m}$

$\mathrm{h} \quad$ convective heat transfer coefficient, $\mathrm{W} \mathrm{m}^{-2} \mathrm{~K}^{-1}$

$\mathrm{k}$ thermal conductivity, $\mathrm{W} \mathrm{m}^{-1} \mathrm{~K}^{-1}$

$\mathrm{L} \quad$ periodic length of the physical model, $\mathrm{m}$

$\mathrm{Nu} \quad$ Nusselt number $(=\mathrm{hD} / \mathrm{k})$

$\mathrm{P} \quad$ pitch distance between inclined rings, $\mathrm{m}$

$\mathrm{p} \quad$ static pressure, $\mathrm{Pa}$

Re Reynolds number

s gap distance among the outer border of DVO and duct wall,

$\mathrm{m}$

$\mathrm{T} \quad$ temperature, $\mathrm{K}$

$\bar{u} \quad$ mean velocity in channel, $\mathrm{m} \mathrm{s}^{-1}$

Greek letter

$\rho \quad$ density, $\mathrm{kg} \mathrm{m}^{-3}$

$\mu \quad$ dynamic viscosity, $\mathrm{kg} \mathrm{m}^{-1} \mathrm{~s}^{-1}$

Subscript

$0 \quad$ plain duct

pp pumping power

Abbreviation

DVO Double V-Orifice

TEF Thermal Enhancement Factor $\left(=\left(\mathrm{Nu} / \mathrm{Nu}_{0}\right) /\left(\mathrm{f} / \mathrm{f}_{0}\right)^{1 / 3}\right)$

\section{REFERENCE}

Ahmed, H.E., Salman, B.H., and Kerbeet, A.S., 2019, "Heat Transfer Enhancement of Turbulent Forced Nanofluid Flow in a Duct Using Triangular Rib", International Journal of Heat and Mass Transfer, 134, $30-40$.

https://doi.org/10.1016/j.ijheatmasstransfer.2018.12.163

Ameur, H., and Menni, Y., 2019, "Laminar Cooling of Shear Thinning Fluids in Horizontal and Baffled Tubes: Effect of Perforation in Baffles", Thermal Science and Engineering Progress, 14, Article 100430.

https://doi.org/10.1016/j.tsep.2019.100430

Arani, A.A.A., and Moradi, R., 2019, "Shell and Tube Heat Exchanger Optimization Using New Baffle and Tube Configuration", Applied Thermal Engineering, 157, Article 113736.

https://doi.org/10.1016/j.applthermaleng.2019.113736

Bahiraei, M., Gharagozloo, K., and Moayedi, H., 2020, "Experimental Study on Effect of Employing Twisted Conical Strip Inserts on Thermohydraulic Performance Considering Geometrical Parameters", International Journal of Thermal Sciences, 149, 106178. https://doi.org/10.1016/j.ijthermalsci.2019.106178

Bahiraei, M., Mazaheri, N., and Moayedi, H., 2020, "Employing Vshaped Ribs and Nanofluid as Two Passive Methods to Improve Second Law Characteristics of Flow within a Square Channel: A Two-phase 
Approach", International Journal of Heat and Mass Transfer, 151, 119419.

https://doi.org/10.1016/j.ijheatmasstransfer.2020.119419

Bahiraei, M., Mazaheri, N., and Moayedi, H., 2020, "Entropy Generation and Exergy Destruction for Flow of a Biologically Functionalized Graphene Nanoplatelets Nanofluid within Tube Enhanced with a Novel Rotary Coaxial Cross Double-twisted Tape", International Communications in Heat and Mass Transfer, 113, 104546.

https://doi.org/10.1016/j.icheatmasstransfer.2020.104546

Bahiraei, M., Mazaheri, N., and Rizehvandi, A., 2019, “Application of a Hybrid Nanofluid Containing Graphene Nanoplatelet-platinum Composite Powder in a Triple-tube Heat Exchanger Equipped with Inserted Ribs", Applied Thermal Engineering, 149, 588-601.

https://doi.org/10.1016/j.applthermaleng.2018.12.072

Bahiraei, M., Mazaheri, N., Hosseini, Y., and Moayedi, H., 2019, “A Two-phase Simulation for Analyzing Thermohydraulic Performance of $\mathrm{Cu}$-water Nanofluid within a Square Channel Enhanced with $90^{\circ} \mathrm{V}$ shaped Ribs", International Journal of Heat and Mass Transfer, 145, Article 118612.

https://doi.org/10.1016/j.ijheatmasstransfer.2019.118612

Bahiraei, M., Monavari, A., and Moayedi, H., 2020, "Second Law Assessment of Nanofluid Flow in a Channel Fitted with Conical Ribs for Utilization in Solar Thermal Applications: Effect of Nanoparticle Shape", International Journal of Heat and Mass Transfer, 151, 119387. https://doi.org/10.1016/j.ijheatmasstransfer.2020.119387

Bai, W., Chen, W., Yang, L., and Chyu, M.K., 2019, "Numerical Investigation on Heat Transfer and Pressure Drop of Pin-fin Array under the Influence of Rib Turbulators Induced Vortices", International Journal of Heat and Mass Transfer, 129, 735-745.

https://doi.org/10.1016/j.ijheatmasstransfer.2018.10.022

Bai, W., Liang, D., Chen, W., and Chyu, M.K., 2019, "Investigation of Ribs Disturbed Entrance Effect of Heat Transfer and Pressure Drop in Pin-fin Array", Applied Thermal Engineering, 162, Article 114214. https://doi.org/10.1016/j.applthermaleng.2019.114214

Boonloi, A., and Jedsadaratanachai, W., 2019a, "The Effect of Gap Spacing Ratio on Flow Structure and Heat Transfer Characteristic for the V-orifice in the Square Channel Heat Exchanger", Frontiers in Heat and Mass Transfer, 12, 19.

https://doi.org/10.5098/hmt.12.19

Boonloi, A., and Jedsadaratanachai, W., 2019b, "Influence of Ring Size and Location on Flow Topology, Heat transfer Structure and Thermal Efficiency in Heat Exchanger Square Channel Placed with 30-degree Inclined Square Ring", Frontiers in Heat and Mass Transfer, 13, 28. https://doi.org/10.5098/hmt.13.28

Boonloi, A., and Jedsadaratanachai, W., 2019c, "Flow and Heat Transfer Characteristics of Air in Square Channel Heat Exchanger with C-shaped Baffle: A Numerical Study", Frontiers in Heat and Mass Transfer, 13, 23.

https://doi.org/10.5098/hmt.13.23

Cao, X., Du, T., Liu, Z., Zhai, H., and Duan, Z., 2019, "Experimental and Numerical Investigation on Heat Transfer and Fluid Flow Performance of Sextant Helical Baffle Heat Exchangers", International Journal of Heat and Mass Transfer, 142, Article 118437.

https://doi.org/10.1016/j.ijheatmasstransfer.2019.118437
Cengel, Y.A., and Ghajar, A.J., 2015, "Heat and Mass Transfer: Fundamentals \& Applications, Fifth edition in SI Units", McGraw-Hill Education, ISBN 978-981-4595-27-8.

Chai, L., Wang, L., and Bai, X., 2018, "Thermohydraulic Performance of Microchannel Heat Sinks with Triangular Ribs on Sidewalls - Part 1: Local Fluid Flow and Heat Transfer Characteristics", International Journal of Heat and Mass Transfer, 127, 1124-1137. https://doi.org/10.1016/j.ijheatmasstransfer.2018.08.114

Chai, L., Wang, L., and Bai, X., 2019, "Thermohydraulic Performance of Microchannel Heat Sinks with Triangular Ribs on Sidewalls - Part 2: Average Fluid Flow and Heat Transfer Characteristics", International Journal of Heat and Mass Transfer, 128, 634-648.

https://doi.org/10.1016/j.ijheatmasstransfer.2018.09.027

Chen, Y., Tang, H., Wu, J., Gu, H., and Yang, S., 2019, "Performance Comparison of Heat Exchangers using Sextant/trisection Helical Baffles and Segmental Ones", Chinese Journal of Chemical Engineering, 27, 2892-2899.

https://doi.org/10.1016/j.cjche.2019.07.006

Ibrahim, M.M., Essa, M.A., and Mostafa, N.H., 2019, “A Computational Study of Heat Transfer Analysis for a Circular Tube with Conical Ring Turbulators", International Journal of Thermal Sciences, 137, 138-160.

https://doi.org/10.1016/j.ijthermalsci.2018.10.028

Jedsadaratanachai, W., and Boonloi, A., 2014, "Effects of Blockage Ratio and Pitch Ratio on Thermal Performance in a Square Channel with $30^{\circ}$ Double V-baffles", Case Studies in Thermal Engineering, 4, 118-128.

https://doi.org/10.1016/j.csite.2014.08.002

Jedsadaratanachai, W., Jayranaiwachira, N., and Promvonge, P., 2015, "3D Numerical Study on Flow Structure and Heat Transfer in a Circular Tube with V-baffles", Chinese Journal of Chemical Engineering, 23, 342-349.

https://doi.org/10.1016/j.cjche.2014.11.006

Jedsadaratanachai, W., Suwannapan, S., and Promvonge, P., 2011, "Numerical Study of Laminar Heat Transfer in Baffled Square Channel with Various Pitches", Energy Procedia, 9, 630-642.

https://doi.org/10.1016/j.egypro.2011.09.073

Karami, M., Tashakor, S., Afsari, A., and Tilehnoee, M.H., 2019, "Effect of the Baffle on the Performance of a Micro Pin Fin Heat Sink", Thermal Science and Engineering Progress, 14, Article 100417. https://doi.org/10.1016/i.tsep.2019.100417

Li, Y., Rao, Y., Wang, D., Zhang, P., and Wu, X., 2019, "Heat Transfer and Pressure Loss of Turbulent Flow in Channels with Miniature Structured Ribs on One Wall", International Journal of Heat and Mass Transfer, 131, 584-593.

https://doi.org/10.1016/j.ijheatmasstransfer.2018.11.067

Liu, P., Lv, J., Shan, F., Liu, Z., and Liu, W., 2019, "Effects of Rib Arrangements on the Performance of a Parabolic Trough Receiver with Ribbed Absorber Tube", Applied Thermal Engineering, 156, 1-13.

https://doi.org/10.1016/j.applthermaleng.2019.04.037 
Mohammed, H.A., Abuobeida, I.A.M.A., Vuthaluru, H.B., and Liu, S., 2019, "Two-phase Forced Convection of Nanofluids Flow in Circular Tubes using Convergent and Divergent Conical Rings Inserts", International Communications in Heat and Mass Transfer, 101, 10-20. https://doi.org/10.1016/j.icheatmasstransfer.2018.12.010

Nakhchi, M.E, and Esfahani, J.A., 2019a, "Numerical Investigation of Turbulent $\mathrm{Cu}$-water Nanofluid in Heat Exchanger Tube Equipped with Perforated Conical Rings", Advanced Powder Technology, 30, 7, 13381347.

https://doi.org/10.1016/j.apt.2019.04.009

Nakhchi, M.E., and Esfahani, J.A., 2019b, "Numerical Investigation of Different Geometrical Parameters of Perforated Conical Rings on Flow Structure and Heat Transfer in Heat Exchangers", Applied Thermal Engineering, 156, 494-505.

https://doi.org/10.1016/j.applthermaleng.2019.04.067

Patankar, S.V., Liu, C.H., and Sparrow, E.M., 1977, "Fully Developed Flow and Heat Transfer in Ducts Having Streamwise-Periodic
Variations of Cross-Sectional Area", Journal of Heat Transfer, 99, 180186.

https://doi.org/10.1115/1.3450666

Promvonge, P., Jedsadaratanachai, W., and Kwankaomeng, S., 2010, "Numerical study of laminar flow and heat transfer in square channel with $30^{\circ}$ inline angled baffle turbulators", Applied Thermal Engineering, 30, 292-1303.

https://doi.org/10.1016/j.applthermaleng.2010.02.014

Promvonge, P., Jedsadaratanachai, W., Kwankaomeng, S., and Thianpong, C., 2012, "3D Simulation of Laminar Flow and Heat Transfer in V-baffled Square Channel”, International Communications in Heat and Mass Transfer, 39, 85-93.

https://doi.org/10.1016/j.icheatmasstransfer.2011.09.004

Wang, G., Qian, N., and Ding, G., 2019, "Heat Transfer Enhancement in Microchannel Heat Sink with Bidirectional Rib", International Journal of Heat and Mass Transfer, 136, 597-609.

https://doi.org/10.1016/j.ijheatmasstransfer.2019.02.018 